\title{
Effect of work posture on operator complaints: Choice between sitting and standing work
}

\author{
Anizar Anizar ${ }^{*}$, Rahmi M Sari ${ }^{1}$, Khalida Syahputri ${ }^{1}$, Indah Rizkya ${ }^{1}$, and Nurul Atikah ${ }^{1}$ \\ ${ }^{1}$ Universitas Sumatera Utara, Department of Industrial Engineering, Faculty of Engineering, Medan 20155, Indonesia
}

\begin{abstract}
Workers perform manual handling activities with sitting and standing work postures. In sitting work posture, this activity is performed using a 15 -cm-long spade, so the workers must bend both their bodies and feet, meanwhile in standing work posture, workers use stainless steel squeegee. Workers on both postures complain of pain but on different parts of the body. Limited work facilities cause this handling activity uses body muscle repetitively. The aim of this study is to obtain an ergonomic work facility so that workers can use standing work posture with minimal pain complaints. The methods used are arterial pulse measurement, pain complaints measurement, anthropometry measurement, and designing handling device using QFD method. The subjects in this study are 6 male workers in a steel company producing threaded steel. The handling device stands $77.9 \mathrm{~cm}$ tall with a $15^{\mathrm{O}}$ slope so that silicomanganese can move down by taking advantage of the vibration. Workers only direct silicomanganese into the sack in standing work posture, so that performance can increase.
\end{abstract}

\section{Introduction}

The industry that uses raw human power in handling and moving materials are still prominent in Indonesia. Manually handling and moving materials has its own advantage, i.e. it can maximize the use of a small room and can even use very traditional and limited tools. This activity can be performed in sitting and standing work posture depends on the facilities available. The drawbacks of this method, however, are pretty serious, back pain stability is a big problem for many. A lower back injury could happen as a consequence of a lost stability of backbones due to fatigue from manually handling material [1]. Long sitting time will take a toll on workers health so that there needs to be a combination of standing and sitting work posture [2-5]. Standing work posture is more productive on manufacture type of work and assembly work, yet work duration is still of a concern because fatigue may happen and a musculoskeletal problem may occur [6-9].

Workstation design is influenced by available work facilities, which will impact on the choice of work posture: standing or sitting. Sitting work posture with both body and feet bent, and performed repetitively in high frequency may cause a physical complaint. Two most obvious direct impacts of physical complaints are a drop in work performance and weary feeling in a musculoskeletal system when doing a work for a long period of time [10]. A good design of a workstation, that is improving work facilities, can directly increase productivity [11].

Workers in a company producing threaded steel perform silicomanganese handling in sitting and standing work posture. Silicomanganese is handled in sitting work posture by taking a sack and moving silicomanganese into the sack using a spade, followed by weighing the sack and tying it, and finally throwing it into a bigger container. This activity is performed manually using a $15-\mathrm{cm}$-long spade. This activity of working in sitting work posture is shown in Fig. 1.

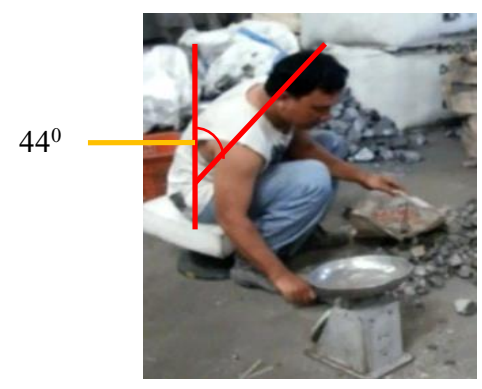

Fig. 1. Working in sitting work posture and actual work facilities.

The handling activity in sitting work posture causes workers too bent his body at about $44^{\circ}$ and also bent his feet, which results in complaints to some parts of his body. In identifying complaints, Standard Nordic Questionnaire (SNQ) is used on the respondents, 6 warehouse workers. The reported complaints from working in sitting work posture usually happen on the lower neck, left and right shoulders, left and right upper arms, waist, bottom, left and right lower arms, left and right calves. This result can increase the risk of complaint in silicomanganese sorting activity, as unsuitable and unergonomic work tools are still used.

\footnotetext{
* Corresponding author: anizar_usu@usu.ac.id
} 


\section{Methods}

This study is conducted in steel manufacturing company producing threaded steel. The handling activity of silicomanganese is performed before production process starts. Workers can handle silicomanganese material as much as 2.5 tons per day in sitting or standing work posture. In sitting work posture, the activity consists of taking a sack and moving the silicomanganese into the sack using a spade, followed by weighing the sack and tying it, and finally throwing it into a bigger container. In standing work posture, the activity consists of positioning a steel bulk tote bin-container, taking a steelsqueegee, moving the substance into the steel bulk tote bin-container, and weighing it.

Respondents in this study are 6 warehouse workers. The observed objects of study are workers in their activity of sorting silicomanganese. Study variables used are work posture, arterial pulse, body part complaints, work facilities attribute design, and workers' body dimension. Work posture is observed in order to assess work level and the result is used to understand which work postures need improving. Arterial pulses of workers before and after work are measured as Rest Arterial Pulse (RAP) at 13.00 and Work Arterial Pulse (WAP) at 17.00 respectively. SNQ is a questionnaire designed in order to identify workers body complaints during this sorting activity. SNQ is given to 6 workers and classification is used to know muscles that are complained. The percentage of complaints experienced on each body part can be calculated with :

$\%$ Complaint $=\frac{\text { number of workers experiencing muscular pain complaint }}{\text { number of workers }} \times 100 \%$

The attributes of work facilities design that workers wanted are obtained using open and closed questionnaire. Improvement ratio for each importance level is calculated using:

$$
\text { Improvement Ratio }=\frac{\text { Goal }}{\text { Current Satisfaction Performance }}
$$

Raw weight for each need is calculated using:

Raw Weight $=$ Importance to Customer $\times$ Improvement Ratio $\times$ Sales Point

Normalised raw weight for each need is calculated using:

$$
\text { Normalized Raw Weight }=\frac{\text { Raw Weight }}{\text { Raw Weight Total }} \times 100 \%
$$

Anthropometry data are obtained by measuring workers body dimension using human body martin method. Percentiles of 5th, 50th, and 95th for each anthropometry data are calculated using normal distribution, i.e.:

Percentile 5: $\bar{x}-1.645 \sigma_{\mathrm{x}}$ Percentile 50: $\bar{x}$

Percentile 95: $\bar{x}+1.645 \sigma_{\mathrm{x}}$

\section{Result and discussions}

\subsection{Work posture}

The activity of working in sitting work posture consists of taking a sack and moving the silicomanganese into the sack using a spade, followed by weighing the sack and tying it, and finally throwing it into a bigger container. The sitting work posture is shown in Fig. 2.
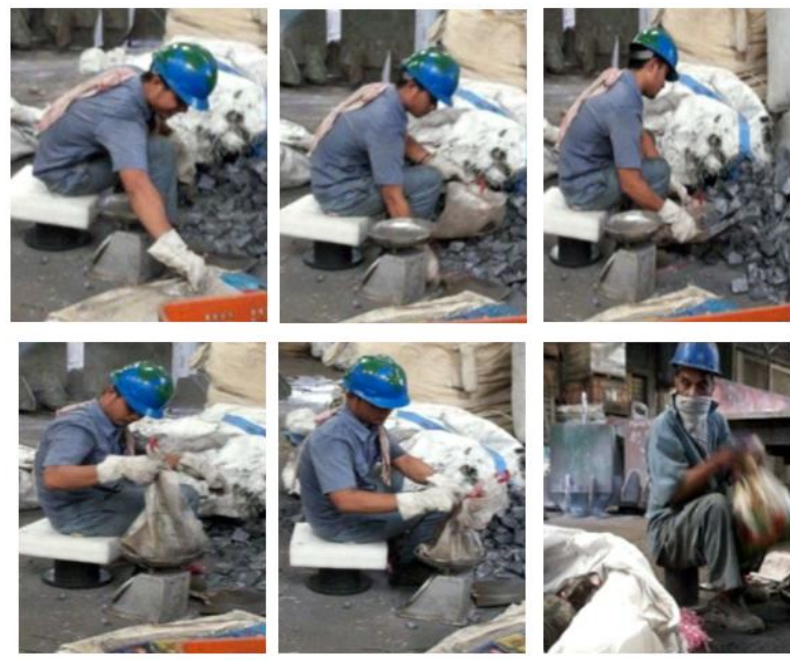

Fig. 2. The activity of sorting silicomanganese in sitting work posture.

The activity of working in standing work posture consists of positioning a steel bulk tote bin-container, taking a steel-squeegee, moving the substance into the steel bulk tote bin-container, and weighing it. The standing work posture is shown in Fig. 3.
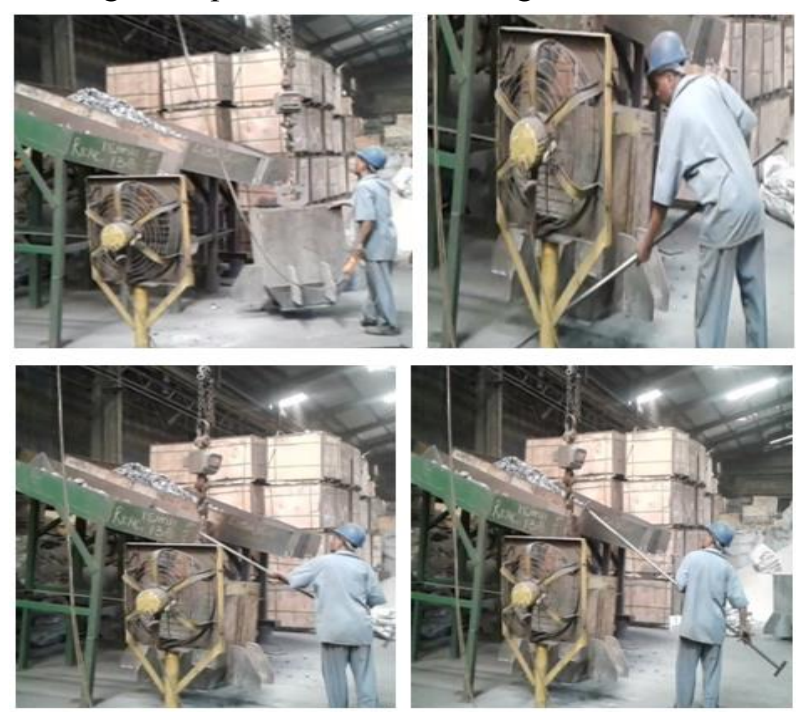

Fig. 3. The activity of sorting silicomanganese in standing work posture.

\subsection{Arterial pulse}

Workers' arterial pulse is measured in pulse per minute (ppm) and is divided into two categories, i.e. Rest Arterial Pulse (RAP) and Work Arterial Pulse (WAP). In general, it can be seen that both RAP and WAP for 
standing work posture is lower than sitting work posture as shown in Table 1. This finding happens for all workers despite their age difference.

Table 1. Arterial pulse of workers in sitting dan standing work posture.

\begin{tabular}{|c|c|c|c|c|c|}
\hline \multirow{2}{*}{ Workers } & \multirow{2}{*}{$\begin{array}{c}\text { Age } \\
\text { (years })\end{array}$} & \multicolumn{2}{|c|}{$\begin{array}{c}\text { Sitting Work } \\
\text { Posture }\end{array}$} & \multicolumn{2}{c|}{$\begin{array}{c}\text { Standing Work } \\
\text { Posture }\end{array}$} \\
\cline { 3 - 6 } & & $\begin{array}{c}\text { RAP } \\
(\mathrm{ppm})\end{array}$ & $\begin{array}{c}\text { WAP } \\
(\mathrm{ppm})\end{array}$ & $\begin{array}{c}\text { RAP } \\
(\mathrm{ppm})\end{array}$ & $\begin{array}{c}\text { WAP } \\
(\mathrm{ppm})\end{array}$ \\
\hline Worker 1 & 33 & 71 & 164 & 66 & 118 \\
\hline Worker 2 & 40 & 69 & 158 & 65 & 115 \\
\hline Worker 3 & 54 & 62 & 147 & 60 & 106 \\
\hline Worker 4 & 51 & 64 & 149 & 61 & 108 \\
\hline Worker 5 & 27 & 78 & 166 & 69 & 119 \\
\hline Worker 6 & 48 & 67 & 154 & 63 & 113 \\
\hline
\end{tabular}

\subsection{Body part complaints}

Complains about some body parts are experienced by all workers, either in sitting or standing work posture. Workers who work in sitting work posture experience pain complaints on their lower neck, left and right shoulders, left and right upper arms, waist, bottom, left and right lower arms, left and right calves. The workers in sitting work posture felt very painful on their left and right calves and felt painful on their left and right upper arm and waist. Meanwhile, workers who work in standing work posture experience pain on 21 body segments $(75 \%)$, although none reports feeling very painful, all workers experience pain on the lower neck, right shoulder, waist, and right hand.

Identification results from these complaints show that workers need improvement in their work facilities in this silicomanganese sorting activity so that this activity can be performed safely in standing work posture. In designing the best ergonomic silicomanganese sorting device, QFD method and anthropometry principles are incorporated.

\subsection{Ergonomic design of measuring table}

Identification of work facilities needed by the customer is conducted through open and closed questionnaire distribution. There are 8 attributes obtained. The identification result is shown in Table 2.

Table 2. Identification results of customer needs.

\begin{tabular}{|c|l|}
\hline No & \multicolumn{1}{|c|}{ Customer Needs } \\
\hline 1 & Frame made of steel \\
\hline 2 & Base container made of rubber \\
\hline 3 & The device works by taking advantage of vibration \\
\hline 4 & The container is rectangular in shape \\
\hline 5 & Weight display is placed in the front \\
\hline 6 & The device is stopped using a cover with a hinge \\
\hline 7 & The device dimension is roughly 250x151x25 cm \\
\hline 8 & Additional features include sack place and rope \\
\hline
\end{tabular}

Customer needs are obtained from the largest number of answer from respondents of an open questionnaire. A steel frame is answered by 4 out of 6 respondents of the open questionnaire.
The design matrix is arranged by setting the importance level of workers need, which is based on the highest number of answer on a closed questionnaire. Importance level of workers need toward silicomanganese handling device is shown on Tabel 3.

Table 3. Importance level of workers needs.

\begin{tabular}{|c|c|c|c|c|c|c|c|}
\hline \multirow{3}{*}{ No } & \multirow{3}{*}{ Workers Needs } & \multirow{2}{*}{\multicolumn{5}{|c|}{$\begin{array}{l}\text { Questionnaire } \\
\text { Result } \\
\begin{array}{c}\text { Measurement } \\
\text { Scale }\end{array}\end{array}$}} & \multirow{3}{*}{$\begin{array}{c}\text { Importance } \\
\text { Level }\end{array}$} \\
\hline & & & & & & & \\
\hline & & 1 & 2 & 3 & 4 & 5 & \\
\hline 1 & Steel frame & 0 & 2 & 0 & 0 & 4 & 5 \\
\hline 2 & $\begin{array}{l}\text { Base container } \\
\text { made of rubber }\end{array}$ & 0 & 0 & 1 & 1 & 4 & 5 \\
\hline 3 & $\begin{array}{l}\text { The device works } \\
\text { by taking } \\
\text { advantage of } \\
\text { vibration }\end{array}$ & 1 & 0 & 0 & 2 & 3 & 5 \\
\hline 4 & $\begin{array}{l}\text { A container is } \\
\text { rectangular in } \\
\text { shape }\end{array}$ & 1 & 1 & 0 & 1 & 3 & 5 \\
\hline 5 & $\begin{array}{l}\text { Weight display is } \\
\text { placed in the front }\end{array}$ & 0 & 0 & 2 & 0 & 4 & 5 \\
\hline 6 & $\begin{array}{l}\text { The device is } \\
\text { stopped using a } \\
\text { cover with a hinge }\end{array}$ & 0 & 1 & 1 & 3 & 1 & 4 \\
\hline 7 & $\begin{array}{l}\text { The device } \\
\text { dimension is } \\
\text { roughly } \\
250 \times 151 \times 25 \mathrm{~cm}\end{array}$ & 1 & 1 & 1 & 2 & 1 & 4 \\
\hline 8 & $\begin{array}{l}\text { Additional } \\
\text { features include } \\
\text { sack place and } \\
\text { rope }\end{array}$ & 0 & 0 & 2 & 1 & 3 & 5 \\
\hline
\end{tabular}

Importance level of handling device design is obtained from the largest number of respondents of a closed questionnaire. Steel frame with the importance level of 5 scales is answered by 4 out of 6 respondents. Sales point is set by every user need based on priority. Design matrix of handling device is shown in Table 4.

Table 4. Design matrix of measuring table.

\begin{tabular}{|l|c|c|c|}
\hline \multicolumn{1}{|c|}{$\begin{array}{c}\text { Customer } \\
\text { Requirement }\end{array}$} & $\begin{array}{c}\text { Sales } \\
\text { Point }\end{array}$ & $\begin{array}{c}\text { Raw } \\
\text { Weight }\end{array}$ & $\begin{array}{c}\text { Normalized } \\
\text { Raw Weight }\end{array}$ \\
\hline Steel frame & 1.5 & 9.375 & 17.599 \\
\hline $\begin{array}{l}\text { Base container made } \\
\text { of rubber }\end{array}$ & 1 & 5.5555 & 10.429 \\
\hline $\begin{array}{l}\text { The device works by } \\
\text { taking advantage of } \\
\text { vibration }\end{array}$ & 1 & 6.25 & 11.733 \\
\hline $\begin{array}{l}\text { A container is } \\
\text { rectangular in shape }\end{array}$ & 1 & 6.8181 & 12.799 \\
\hline $\begin{array}{l}\text { Weight display is } \\
\text { placed in the front }\end{array}$ & 1.5 & 8.6538 & 16.246 \\
\hline $\begin{array}{l}\text { The device is stopped } \\
\text { using a cover with a } \\
\text { hinge }\end{array}$ & 1 & 4.3636 & 8.1917 \\
\hline $\begin{array}{l}\text { The device dimension } \\
\text { is roughly 250x151x25 } \\
\text { cm }\end{array}$ & 1 & 5.0526 & 9.4851 \\
\hline $\begin{array}{l}\text { Additional features } \\
\text { include sack }\end{array}$ & 1.2 & 7.2 & 13.516 \\
\hline
\end{tabular}


Steel frame with sales point of 1.5 means that it is a need that has a high impact on an increase in company profit. Raw weight of 9.375 is obtained from formula (3). The normalized weight of 17.599 is obtained from formula (4). Technical characteristics of work facilities are shown in Table 5.

Table 5. Technical characteristics of work facilities.

\begin{tabular}{|c|l|}
\hline No & \multicolumn{1}{|c|}{ Technical Response } \\
\hline 1 & Material durability \\
\hline 2 & Welding strength \\
\hline 3 & Vibration produced \\
\hline 4 & Layering quality \\
\hline 5 & Ease of use \\
\hline 6 & Paint quality \\
\hline
\end{tabular}

Technical characteristics are identified in order to understand the procedure of manufacture to make handling device. Technical characteristics are needed by a producer to meet workers need of handling device design. The target that must be met by each technical characteristics is determined by setting House of Quality (HoQ), so that performance quantity of $\mathrm{HoQ}$ is calculated first, which consists of determining difficulty level, importance level, and cost prediction.

HoQ matrix consists of QFD arrangement of silicomanganese handling device as shown in Figure 4.

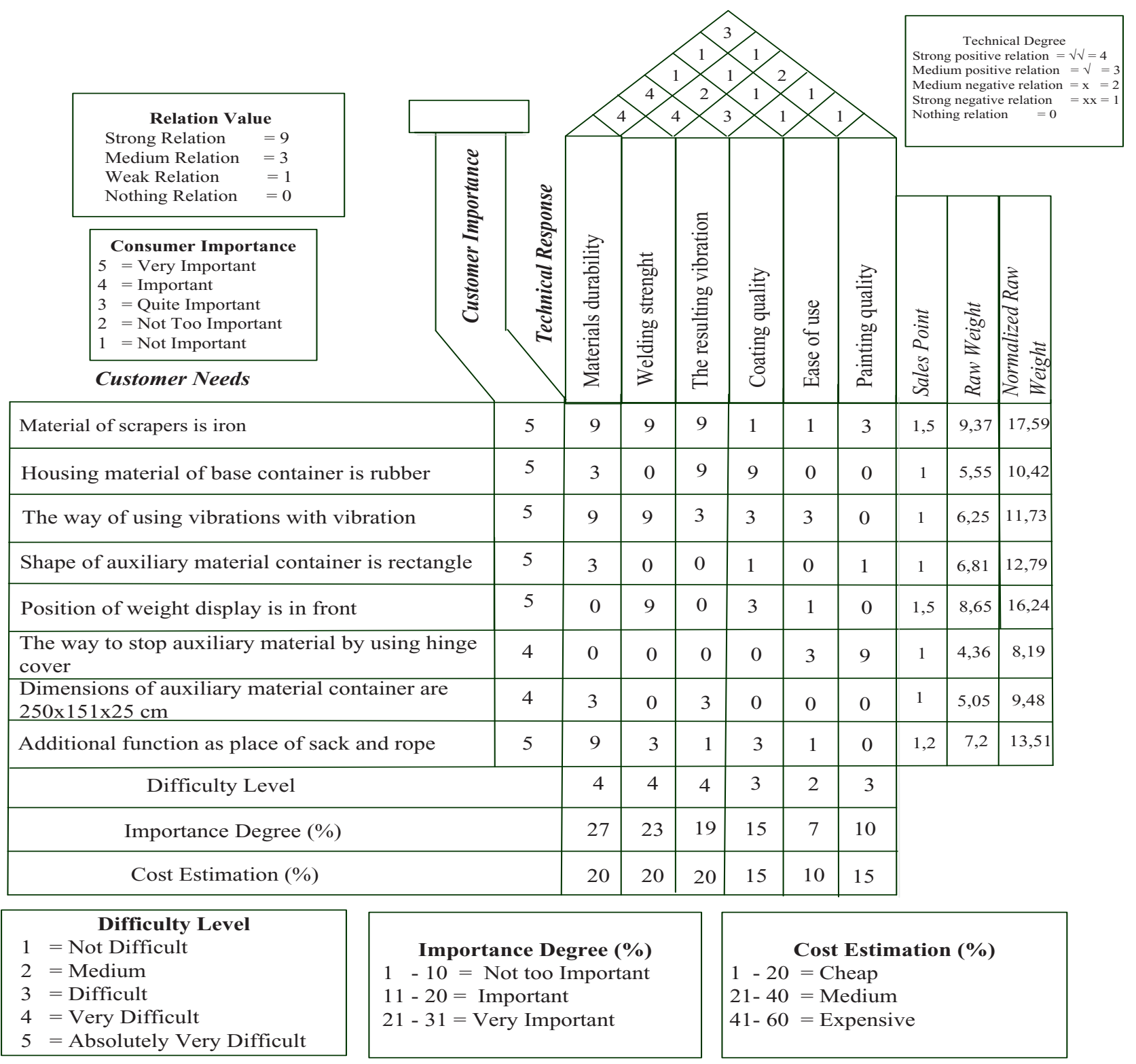

Fig 4. Recapitulation of quality function deployment for silicomanganese handling device.

Technical characteristics of material durability, welding strength, and vibration produced to become the main factor in designing this handling device since they have a high correlation for the development of an ergonomic design. The three characteristics have a high difficulty level, i.e. 4, which means they are the main concern of these design. 


\subsection{Determination of dimension based on anthropometry principles}

Body dimension measurement, used as a reference in designing silicomanganese handling device, is conducted on warehouse workers and other operators, and also by adding more data from the laboratory of Ergonomic and Work System Design. Workers' anthropometry measured are Standing Elbow Height (SEH) to obtain the height of the handling device, Wingspan (WS) to obtain the length of the device, and the distance from elbow to fingertip (ETF) is used to obtain the width of the device, so that when workers do not have to bend when moving sacks and ropes.

The handling device uses the 50th percentile for $\mathrm{SEH}$, the 5th percentile for WS, and the 5th percentile for ETF. The use of these percentiles is shown in Table 6.

Table 6. Recapitulation of anthropometry percentile 5,50,95.

\begin{tabular}{|l|c|c|c|}
\hline \multicolumn{1}{|c|}{ Anthropometry } & $\begin{array}{c}\text { P5 } \\
\text { (cm) }\end{array}$ & $\begin{array}{c}\text { P50 } \\
\text { (cm) }\end{array}$ & $\begin{array}{c}\text { P95 } \\
\text { (cm) }\end{array}$ \\
\hline $\begin{array}{l}\text { Standing Elbow Height } \\
\text { (SEH) }\end{array}$ & 92.175 & $\mathbf{1 0 0 . 4}$ & 108.625 \\
\hline Wingspan(WS) & $\mathbf{1 5 1 . 2 9 5}$ & 166.1 & 180.905 \\
\hline $\begin{array}{l}\text { Elbow to Fingertip } \\
\text { (ETF) }\end{array}$ & $\mathbf{4 0 . 4 8 7}$ & 44.6 & 48.712 \\
\hline
\end{tabular}

The handling device is automatically filled silicomanganese to a sack of $45 \mathrm{~cm}$ in height and $30 \mathrm{~cm}$ in width. This makes the device stand $77.9 \mathrm{~cm}$ tall, that is standing elbow height minus half sack height. The length of the device is set to $151.295 \mathrm{~cm}$, according to the 5 th percentile of wingspan with the minimum number. The width of the device is set $40.487 \mathrm{~cm}$ according to the 5th percentile of an elbow to fingertip distance with the minimum number. The handling device can also be moved around easily. This silicomanganese handling device, as shown in Figure 5, is ergonomic in design, as it takes workers body dimension into account so that workers can easily perform the handling activity.

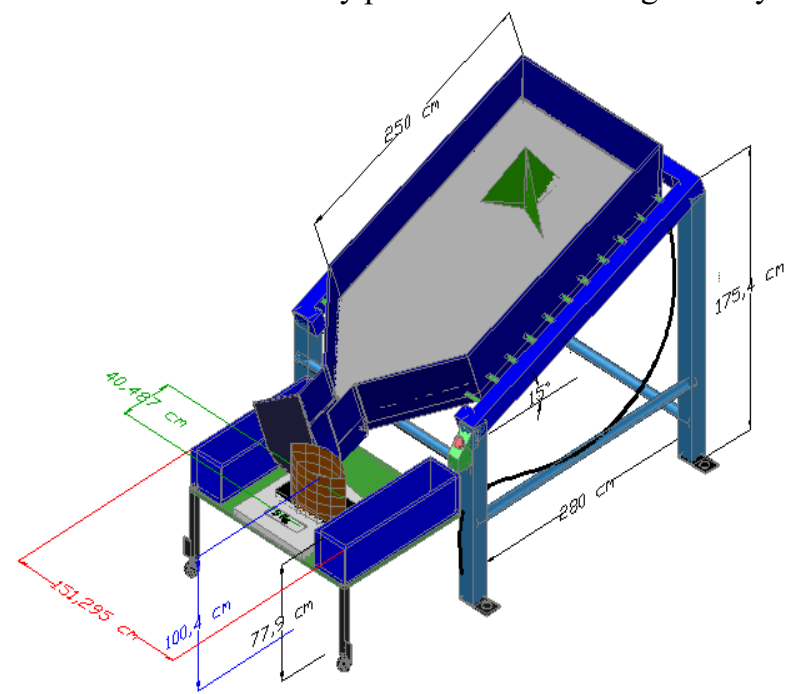

Fig. 5. The ergonomic design of silicomanganese handling device.

\section{Conclusions}

In silicomanganese handling activity, workers who use sitting work posture complain of feeling painful and very painful on $67.85 \%$ body segments, while workers who use standing work posture only complain of feeling painful on $75 \%$ body segments. The use of silicomanganese handling device can reduce the complaints as the workers will be able to use standing work posture. The device is designed by taking workers' body dimension into account: the height of elbow in a standing posture, wingspan, and the distance from elbow to fingertip. The dimension of this device is $77.9 \mathrm{~cm}$ tall, 51.295 long, and 40.487 wide. This device has a slope of $15^{\mathrm{O}}$ so that it can move by taking advantage of vibration. The container is rectangular in shape, with the dimension of $250 \mathrm{~cm} \times 151 \mathrm{~cm} \times 25 \mathrm{~cm}$ and the weight display is on the front side. A cover with a hinge is used to stop silicomanganese from falling to the sack.

\section{References}

1. G. Kevin P, W. Sara E, M. Amy. Proceedings of the Human Factors and Ergonomics Society ... Annual Meeting. 2 (2001)

2. C. Josephine Y, D. Michelle, D. Scott, S. Anu, D. Anna, IJBNPA 11 (2014)

3. H. Nyssa T, W. Lisa, L. Anthony D, M. Keti, D. David W. IJBNPA 14 (2017)

4. G. Lee E F, M. Rebecca C, S. Sam O, C. Josephine, H. Nicola D. BMC Public Health; 15(1) (2015)

5. DM. Hallman, N. Gupta, SE. Mathiassen, A. Holtermann. Int Arch Occup Environ Health; 88(8) (2015)

6. D. Baba Mohd, Y. Abdul Rahman Mohd, I. Solehah Jamilah, D. Dian Darina Indah. IJPH 45(1) (2016)

7. T. Alicia A, K. Bronwyn A, O. Neville, D. David W. Occup Environ Med. 71(11) (2014)

8. EA. Beers, JN. Roemmich, LH. Epstein, PJ. Horvath. Eur J Appl Physiol. 103(3) (2008)

9. K. Messing, F. Tissot, S. Stock, AJPH. 98(4) (2008)

10. A. Toomingas, M. Forsman, SE. M. Heiden, T. Nilsson, BMC Public Health. 12 (2012)

11. V. Deepa, K. Seema, S. Suneeta, K. Nirmal. Indian J Occup Environ Med.16(2) ( 2012) 